\title{
Plasticity in Hippocampal Peptidergic Systems Induced by Repeated Electroconvulsive Shock
}

\author{
Xin-Ming Ma, Richard E. Mains, and Betty A. Eipper
}

The regulated secretion of bioactive peptides requires the coordinated actions of a variety of gene products ranging from peptide precursors to post-translational processing enzymes and the cytosolic machinery involved in vesicle exocytosis. To evaluate the role of plasticity of peptidergic processes in the clinical response to electroconvulsive treatment, we monitored expression of a peptide (neuropeptide $Y, N P Y)$, a post-translational processing enzyme (peptidylglycine $\alpha$-amidating monooxygenase, $P A M)$ and a cytosolic component involved in peptide secretion and neurite extension (kalirin) in the hippocampus. Adult male rats were subjected to single or repeated electroconvulsive shock. In general, levels of NPY, PAM and kalirin mRNA showed similar transient increases after acute and repeated electroconvulsive shock. In contrast, repeated, but not acute, electroconvulsive shock brought about widespread changes in protein expression. Increased amounts of NPY and PAM accumulated in mossy fibers, and dentate granule cell dendrites contained increased amounts of NPY, PAM and kalirin. CA1 pyramidal neurons expressed increased amounts of PAM and kalirin, with an accumulation of both proteins in their dendrites. Scattered interneurons contained increased levels of NPY and PAM after acute and repeated shocks. However, scattered interneurons contained increased levels of kalirin only after repeated shocks. The distinctly different effects of repeated vs. acute electroconvulsive shock support an important role for peptidergic plasticity in the therapeutic effects observed following electroconvulsive treatment. [Neuropsychopharmacology 27:55-71, 2002] (C) 2002 American College of Neuropsychopharmacology. Published by Elsevier Science Inc.
KEY WORDS: GEF; NPY; Amidation; Cytoskeleton; ECT

Electroconvulsive treatment (ECT) is one of the most effective therapies for depression (Abrams 1992; Kelsey and Nemeroff 1998; Fink 2001). Although the mechanisms through which ECT works are not well understood, it is clear that repeated treatments (6-14 on average) are necessary before a therapeutic effect is observed. Electroconvulsive shock (ECS) applied to animals serves as a model for ECT (Green and Nutt 1987). Clinical data and

From the University of Connecticut Health Center, Department of Neuroscience, Farmington, CT 06030.

Address correspondence to: Betty A. Eipper, University of Connecticut Health Center, Department of Neuroscience, MC3401 263 Farmington Avenue, Farmington, CT 06030-3401, Tel.: (860) 6798898, Fax: (860) 679-1885, E-mail: eipper@uchc.edu

Received September 10，2001; revised November 6, 2001; accepted December 18, 2001.

From the Online publication: $1 / 10 / 02$ at www.acnp.org/citations/Npp011002221.
ECS studies support a role for neuropeptides in depression (Mathe 1999; Jimenez-Vasquez et al. 2000). However, the effects of repeated ECS on markers of peptidergic function have not been systematically evaluated.

Changes in a variety of neuropeptides and peptide growth factors are associated with depression (Kubek et al. 1985; Widerlöv et al. 1986; Kanamatsu et al. 1986; Stenfors et al. 1989; Orzi et al. 1990; Zetterstrom et al. 1998; Mathe 1999; Pekary et al. 1999, 2000). For example, depressed patients have decreased levels of cerebrospinal fluid neuropeptide Y (NPY) (Widerlöv et al. 1986, 1988; Gjerris et al. 1992). Repeated ECS increases hippocampal NPY levels toward normal in depressed animal models (Mathe et al. 1998) and several peptide antagonists are being tested as treatments for depression ( $\mathrm{Zo}-$ bel et al. 2000, Argyropoulos and Nutt 2000).

The regulated secretion of neuropeptides requires precursor synthesis, post-translational modifications, and packaging and trafficking of secretory granules. We 
sought indicators of each of these steps. We selected NPY for its anti-seizure role and responsiveness to ECS (Baraban et al. 1997; DePrato-Primeaux et al. 2000). Repeated ECS increased pre-proNPY mRNA levels in the hippocampal dentate hilus, NPY immunoreactivity and release (Wahlestedt et al. 1990; Kragh et al. 1994; Mikkelsen et al. 1994; Zachrisson et al. 1995; Jimenez Vasquez et al. 2000; Husum et al. 2000). Since peptide amidation is a rate limiting step in the biosynthesis of NPY and many other neuropeptides, we monitored peptidylglycine $\alpha$-amidating monooxygenase (PAM), the only enzyme that catalyzes this modification (Prigge et al. 2000). POMC biosynthesis in melanotropes responds to dopaminergic drugs, and changes in PAM parallel POMC (Oyarce et al. 1996). Earlier studies demonstrated changes in PAM and prohormone convertase 2 mRNA levels in response to acute ECS (Bhat et al. 1993).

We also sought indicators of structural changes that might accompany altered peptide secretion. Kalirin, identified by its ability to interact with routing determinants in the cytosolic domain of PAM, is a GDP/GTP exchange factor for selected Rho family small GTP binding proteins (Alam et al. 1997). Rho proteins mediate cytoskeletal reorganization and play a central role in the specification of dendritic morphology (Threadgill et al. 1997; Hall 1998). An isoform of kalirin with a PDZbinding motif is concentrated in the post-synaptic density fraction, and its over-expression altered spine morphology in mature hippocampal neurons (Penzes et al. $2000,2001)$. Since we previously identified kalirin in several cell types in the hippocampus (Ma et al. 2001), we monitored kalirin expression as a potential indicator of structural changes accompanying alterations in peptidergic systems. By searching for changes unique to repeated ECS, we hoped to identify factors involved in the effective use of ECT.

\section{MATERIALS AND METHODS}

\section{Animals and Tissue Preparation}

Adult male Sprague Dawley rats from Charles River Laboratories (250-300g) were housed three per cage with a 14/10 h light-dark cycle with food and water available ad libitum for five days prior to study. All experiments were conducted in accordance with the guidelines established by the Johns Hopkins University School of Medicine and University of Connecticut Health Center Animal Care and Use Committees. Electroconvulsive shocks were administered as described (Cole et al. 1990). Briefly, a 1-s electroshock consisting of $100-\mathrm{Hz}$, 90-mA, 0.5-ms square-wave pulses was delivered by earclip electrodes using a UGO Basile ECS Unit, Model 708. All rats had generalized tonic-clonic convulsions with hindlimb extension. For acute ECS, animals were sacrificed 4,8 and $24 \mathrm{~h}$ after a single treatment $(\mathrm{n}=8)$. Controls were sacrificed $0 \mathrm{~h}$ after a single sham ECS (earclips were attached but no shock was applied) ( $\mathrm{n}=$ 8). For repeated ECS, rats were divided into three groups: repeat basal animals received ECS once daily for 12 days and were sacrificed without ECS on day 13; repeat ECS animals received ECS once daily for 12 days and were sacrificed $4 \mathrm{~h}$ after a final ECS on day 13; repeat controls received 13 sham ECS treatments and were sacrificed $0 \mathrm{~h}$ after the final sham ECS on day $13(\mathrm{n}=8)$.

For in situ hybridization, fresh brains were rapidly frozen on dry ice. Sixteen $\mu \mathrm{m}$ coronal sections were cut through the hippocampus in a cryostat at $-20^{\circ} \mathrm{C}$, mounted on poly-L-lysine (Sigma, St.Louis, MO) coated slides and stored at $-80^{\circ} \mathrm{C}$ until used for in situ hybridization. For immunohistochemical staining, rats $(n=8)$ were perfused $24 \mathrm{~h}$ after a single ECS; sham controls $(n=8)$ were perfused at the same time. Rats $(n=8)$ subjected to daily ECS for 12 days were perfused $24 \mathrm{~h}$ after the last ECS (on day 13); sham controls were perfused at the same time. All rats were anesthetized with chloral hydrate (Sigma) (40 mg/100 g body weight; Sigma, St. Louis, MO) and perfused transcardially with saline containing $5 \mathrm{U} / \mathrm{ml}$ heparin, followed by $4 \%$ paraformaldehyde in phosphate-buffered saline (PBS). Brains were removed, post-fixed in $4 \%$ paraformaldehyde at $4^{\circ} \mathrm{C}$ for $4 \mathrm{~h}$, and then incubated overnight in $25 \%$ sucrose in PBS, $0.02 \% \mathrm{NaN}_{3}$. Coronal ( $\mathrm{n}=5$, each time point) or sagittal ( $\mathrm{n}=3$, each time point) sections (30 $\mu \mathrm{m}$ ) were prepared on a freezing microtome.

\section{In situ Hybridization}

Riboprobes were made using [ $\left.{ }^{35} \mathrm{~S}\right]-\mathrm{UTP}$ as described (Ma et al. 1999). The kalirin probe (nt 2684-3377 of rat kalirin) encoded part of the spectrin-like region common to all forms of kalirin (Ma et al. 2001). High specific activity antisense (linearized with Spe I) and sense (linearized with Smal I) cRNA probes were generated from the pBluescript-SKII(-) plasmid. The rat PAM probe was generated from an EcoRV / Xmal fragment (nt 221-829 of rat PAM) subcloned into pBluescript-SKII(-). High specific activity antisense (linearized with Xma1) and sense (linearized with EcoRV) PAM cRNA probes were generated using $\mathrm{T} 7$ and $\mathrm{T} 3$ polymerase, respectively. The NPY probe (nt 80-490 of human NPY) encoded part of the human NPY cDNA; rat and human proNPY amino acid sequences are identical. High specific activity antisense (linearized with HindIII) and sense (linearized with BamH1) NPY cRNA probes were generated using T7 and T3 polymerase, respectively. In situ hybridization was performed as described (Ma et al. 1999). Briefly, prior to hybridization, stored sections were airdried at room temperature, fixed with $4 \%$ formalde- 
hyde for $5 \mathrm{~min}$ at room temperature, washed three times with PBS, and then acetylated using $0.25 \%$ acetic anhydride in $0.1 \mathrm{M}$ triethanolamine $/ 0.9 \% \mathrm{NaCl}(\mathrm{pH} 8.0)$ for $10 \mathrm{~min}$ at room temperature. Sections were dehydrated in serial ethanol solutions, defatted in chloroform, and dried before hybridization. Sections were hybridized overnight at $55^{\circ} \mathrm{C}$ with $100 \mu$ l hybridization solution containing $2 \times 10^{6} \mathrm{cpm}$ probe per slide; each slide held 4-6 coronal sections. Nonspecifically hybridized probe was removed by washing slides with $50 \%$ formamide $/ 250 \mathrm{mM} \mathrm{NaCl}$ at $60^{\circ} \mathrm{C}$ for $10-15 \mathrm{~min}$, ribonuclease A treatment for $30 \mathrm{~min}(0.5 \mu \mathrm{g} / \mathrm{ml})$ at $37^{\circ} \mathrm{C}$, followed by three washes with $0.1 \times \mathrm{SSC}$ at $50^{\circ} \mathrm{C}$.

\section{Analysis and Quantification}

For quantification of mRNAs, hippocampal sections and ${ }^{14} \mathrm{C}$-labeled standards (American Radiochemical, St Louis, MO) were exposed to Kodak autoradiography BIOMAX film (Kodak, Rochester, NY) for three days (kalirin), five days (PAM) or four days (NPY). Optical density of autoradiographic film images was measured with a computerized image analysis system (Imaging Research, St. Catherine, Ontario, Canada), using NIH Image software as described (Ma et al. 1999) (http:/rsb. info.nih.giv/nih-image). Optical densities were measured in the granule cells of the dentate gyrus and CA1-3 regions in hippocampus by separately outlining the dentate gyrus or CA1-3 regions. The threshold tool was used to eliminate background signal, leaving the signal in the dentate gyrus or CA1-3 region highlighted for measurement. Optical densities averaged from six sections for each rat were used to calculate group means. The distance between two neighboring sections was $80 \mu \mathrm{m}$; with $16 \mu \mathrm{m}$ sections; we used every fifth section. Results are presented as the mean \pm SEM of the percent change from basal values in sham control rats. For resolution of cellular labeling, slides were subsequently dipped in nuclear emulsion diluted 1:1 with distilled water (NTB2, Kodak, Rochester, NY), exposed for 10 days (kalirin), 18 days (PAM) or 14 days (NPY) at $4^{\circ} \mathrm{C}$ and counterstained with cresyl violet acetate (Sigma). Statistical analyses were performed by 1-way ANOVA followed by Fisher's least significant different procedure test to assess statistical significance between control and experimental groups at each time point; $p<.05$ was considered statistically significant.

\section{Immunohistochemistry}

The specificity of kalirin-spectrin antibody 2582 was reported (Ma et al. 2001). PAM antibody specificity was determined by replacement of PAM antibody (JH629) with pre-immune serum and pre-incubation of PAM antibody with PAM antigen $(10 \mu \mathrm{g} / \mu \mathrm{l})$; staining was eliminated in both controls. The specificity of the NPY antibody (JH3) was reported (Milgram et al. 1996). Freefloating sections $(30 \mu \mathrm{m})$ were washed in PBS and blocked with PBS containing 1\% bovine serum albumin, $2 \%$ normal goat serum (NGS), $0.2 \%$ Triton $\mathrm{X}-100$ for $1 \mathrm{~h}$. After overnight incubation at $4^{\circ} \mathrm{C}$ with primary antibody diluted into blocking solution (kalirin-spectrin antiserum JH2582, 1000-fold; PAM antiserum JH629, 3000-fold; NPY antiserum JH3, 2000-fold), sections were washed three times in PBS and incubated for $1 \mathrm{~h}$ in biotinylated anti-rabbit IgG (Vector, Burlingame, CA) diluted in 2\% NGS. After washing three times with PBS, sections were incubated for $45 \mathrm{~min}$ in $\mathrm{ABC}$ reagent (Vector, Burlingame, CA). Sections were visualized by staining with diaminobenzidine, mounted onto slides, dehydrated with ethanol, cleared with xylene and coverslipped in Permount.

\section{Quantification of Interneurons}

Neurons containing PAM or NPY were manually counted in different strata of the CA1-CA3 subfields and in different subfields of the dentate gyrus; counts were made at a magnification of 200x (using a 20x objective). NPY measurements were made in stratum oriens, radiatum, and pyramidale of CA1 and CA3 and in dentate granule cells, the hilar region and the molecular layer of the dentate gyrus. For PAM and kalirin, measurements were restricted to the stratum oriens and radiatum of CA1 and CA3 and to the molecular layer of the dentate gyrus. PAM cell counts in stratum pyramidale and the dentate granule cells were excluded because immunostaining for PAM in these cells made it difficult to identify interneurons. Measurement of PAM interneurons in the hilar area was also excluded because of intense PAM immunostaining in the mossy fibers going through this region.

Five sections $(30 \mu \mathrm{m})$ were counted for each animal; the mean cell number for each section was used to calculate group means. Data are presented as mean \pm SEM. Five sets of sections were made through the hippocampus of each rat. The first, second, and third sets of sections were used for PAM, NPY, and kalirin immunostaining, respectively. Since the minimum distance between adjacent sections using the same antiserum was $150 \mu \mathrm{m}$, the same neuron was not counted twice in two neighboring sections. Data were compared using a Mann-Whitney (U) test.

\section{RESULTS}

\section{Effect of Acute ECS on Peptidergic Marker mRNA Levels}

Dentate Gyrus. We first used in situ hybridization to evaluate changes in gene expression in response to a single ECS. Kalirin mRNA levels in the granule cells of the dentate gyrus increased within $4 \mathrm{~h}$ after a single 
ECS, reaching their peak at $8 \mathrm{~h}$ (Figure 1, panels A, B, C, E). By $24 \mathrm{~h}$ after ECS, kalirin mRNA levels returned to control (Figure 1, panels D, E). PAM gene expression was measured to facilitate comparisons and to confirm previous findings (Bhat et al. 1993). Levels of PAM mRNA in the granule cells of the dentate gyrus increased more rapidly, reaching maximal values at $4 \mathrm{~h}$; as for kalirin, PAM mRNA returned to control levels $24 \mathrm{~h}$ after a single ECS (Figure 1, panels A1-E1). NPY mRNA became detectable in the dentate granule cells $4 \mathrm{~h}$ after acute ECS
Kalirin: Acute ECS
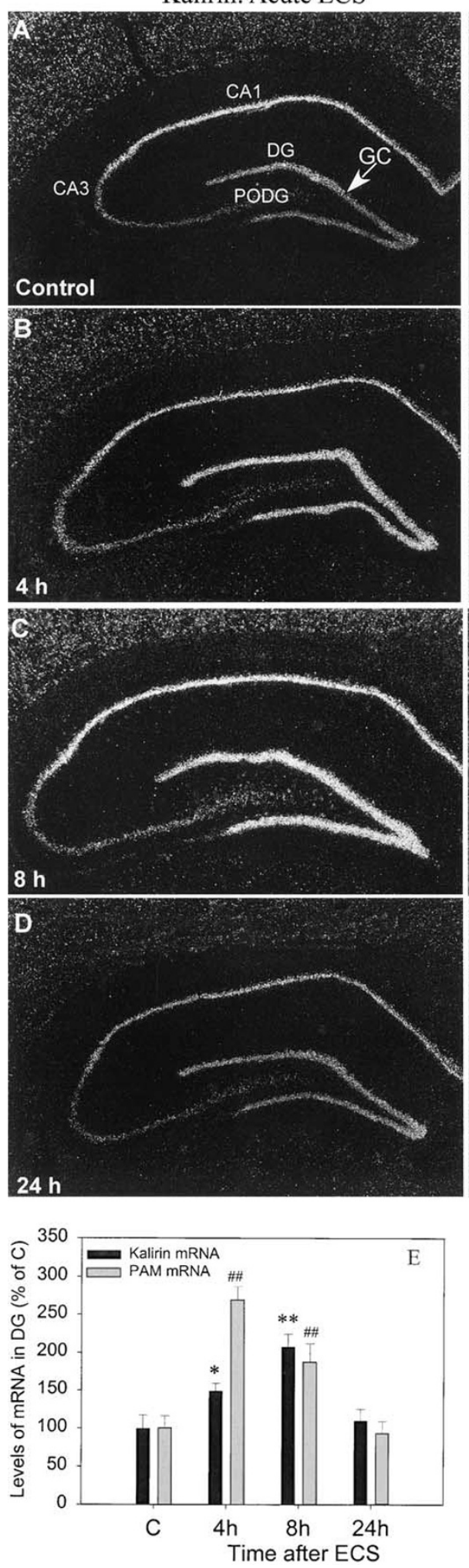

PAM: Acute ECS
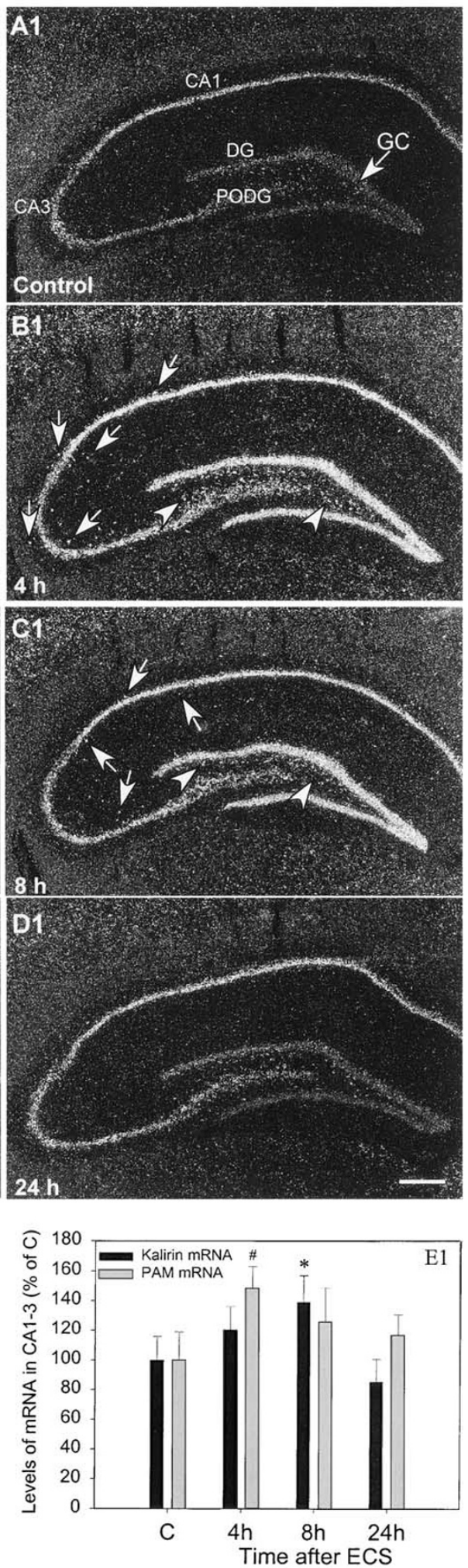

Figure 1. Acute ECS stimulates kalirin and PAM gene expression. Adult male rats were sacrificed at the indicated times after a single ECS. Coronal sections through the hippocampus were hybridized with ${ }^{35}$ S-labeled kalirin or PAM antisense cRNA probes, dipped in emulsion and exposed for 12 days (kalirin) or 18 days (PAM). Darkfield photographs illustrate the response of kalirin (A-D) and PAM (A1-D1) mRNA. Scale bar = $400 \mu \mathrm{m}$. Data for kalirin and PAM mRNA levels in the dentate gyrus (E) and CA1-3 regions (E1) were quantified (see Materials and Methods) and are presented as percent change from control (C). ${ }^{*} p<.05$ vs. $\mathrm{C}^{\#} p<.05$ vs. $\mathrm{C} ;{ }^{* *} p<.01$ vs. $\mathrm{C}$; ${ }^{\# \#} p<.01$ vs. C (by 1-way ANOVA followed by Fisher's PLSD test). The entire experiment was replicated three times with similar results. 
and returned to control levels $24 \mathrm{~h}$ later (Figure 2, panels A-C).

CA1-3 Regions. Kalirin gene expression in the pyramidal neurons of the CA1-3 regions was also responsive to acute ECS. As in the granule cells of the dentate gyrus, levels of kalirin mRNA peaked at $8 \mathrm{~h}$ and returned to control levels $24 \mathrm{~h}$ following a single ECS (Figure 1, panels A-E). The magnitude of the increase in kalirin mRNA levels was less in the CA1-3 regions than in the dentate gyrus (Figure 1, panels A-D, E). PAM mRNA levels in the CA1-3 regions increased more rapidly, with a time course similar to that observed in dentate granule cells (Figure 1, panels B1-C1, E1). Acute ECS also resulted in an increase in levels of kalirin and PAM
mRNA in the polymorph cells (pyramidal cells of CA4) of the dentate gyrus (Figure 1, panels C, B1-C1). NPY mRNA was not detected in the pyramidal cells of CA13 or in the polymorph cells of the dentate gyrus in controls or after acute ECS (Figure 2).

Interneurons. Hippocampal interneurons are a heterogeneous population of non-pyramidal neurons, most of which express $\gamma$-aminobutyric acid (GABA) (Wilson and Nicoll 2001). The number of interneurons expressing kalirin mRNA was unchanged after acute ECS (Figure 1, panels B,C). In contrast, the number of PAM-containing interneurons within the stratum oriens and stratum radiatum of CA1-3 increased $4 \mathrm{~h}$ after acute ECS (Figure 1, panel B1, arrowheads). It is difficult to
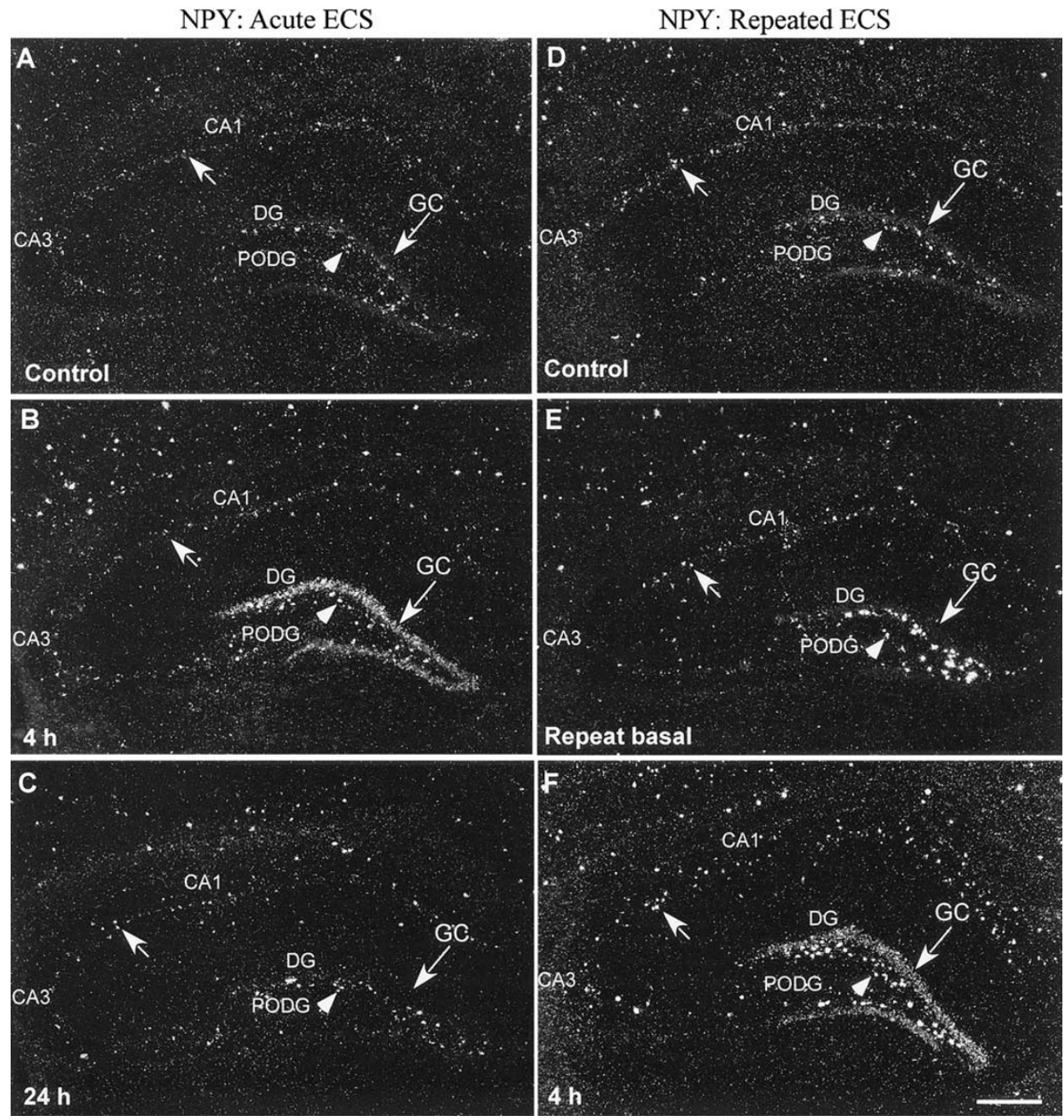

Figure 2. Acute and repeated ECS stimulate NPY gene expression. For acute ECS, adult male rats were sacrificed $4 \mathrm{~h}$ (B) or $24 \mathrm{~h}(\mathrm{C})$ after a single ECS or $4 \mathrm{~h}$ after a sham ECS (A). For repeated ECS, adult male rats were sacrificed $24 \mathrm{~h}$ after $12 \mathrm{sham}$ ECS treatments (Control, D), $24 \mathrm{~h}$ after 12 ECS treatments (Repeat basal, E) or $4 \mathrm{~h}$ after a 13th ECS (4 h, F). Coronal sections through the hippocampus were hybridized with ${ }^{35}$ S-labeled NPY antisense cRNA probe, dipped in emulsion and exposed for 14 days. Scale bar $=400 \mu \mathrm{m}$. 
distinguish interneurons within the stratum pyramidale because of the high levels of PAM mRNA in pyramidal cells. NPY mRNA levels in interneurons, especially in the hilar area, increased dramatically after acute ECS (Figure 2, panel B, arrows).

\section{Effect of Acute ECS on Protein Expression}

Since kalirin, PAM and NPY mRNA levels increased transiently after acute ECS, we evaluated changes in protein level and distribution. To allow time for newly synthesized proteins to accumulate, tissue was examined $24 \mathrm{~h}$
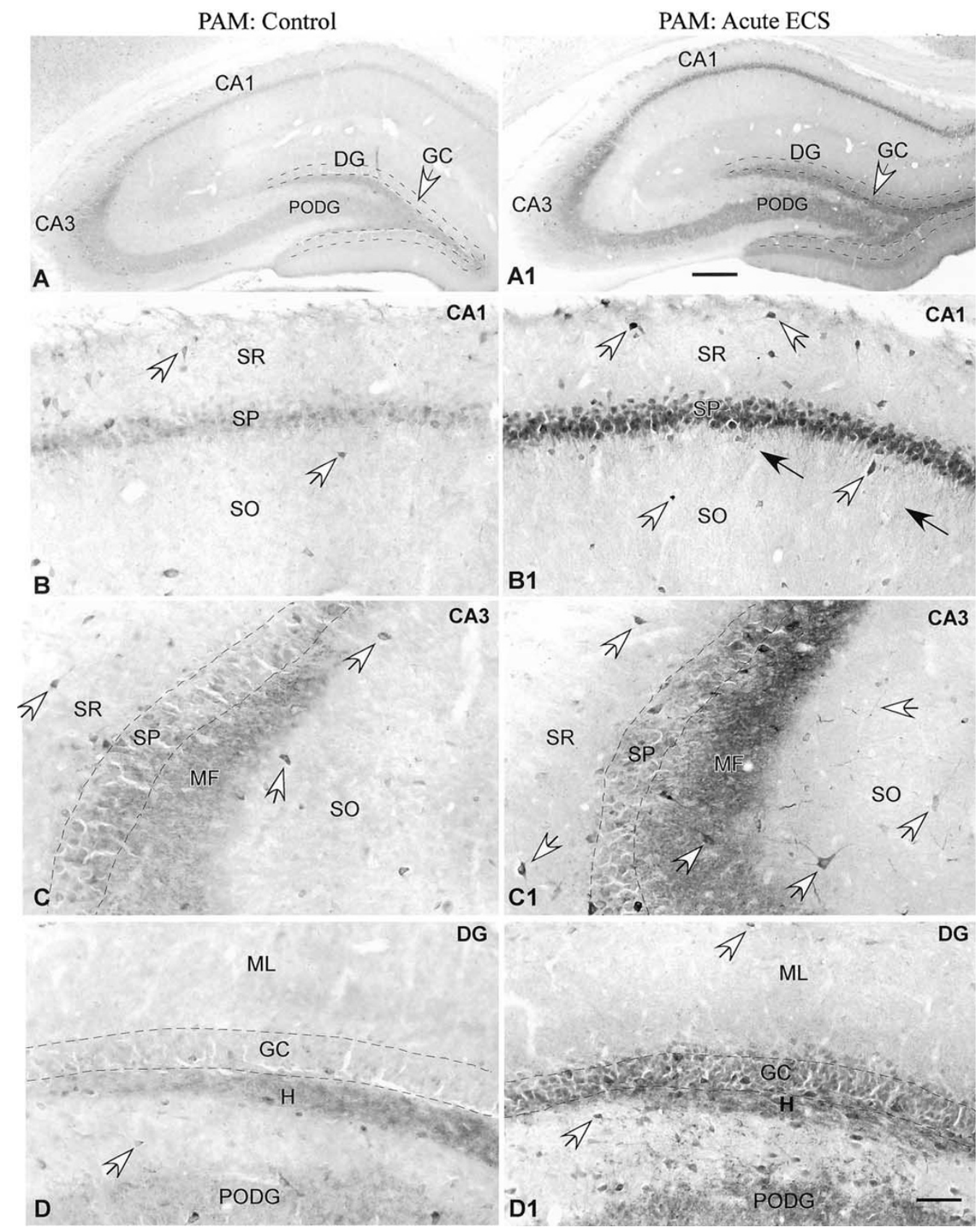

Figure 3. Acute ECS alters expression and localization of PAM. In control animals, PAM was prevalent in CA1-3 pyramidal cells, polymorph cells of the dentate gyrus (PODG), dentate granule cells (GC) and scattered interneurons (white arrows) throughout the hippocampus; PAM was also present in processes in the hilar area $(\mathrm{H})$ and in mossy fibers (MF) (A, B, C \& D). Following acute ECS, PAM immunoreactivity increased in pyramidal cells of CA1-3, PODG, dentate granule cells and scattered interneurons (white arrows); staining in mossy fibers and the hilar area also increased (A1, B1, C1 \& D1). Fine immunoreactive dendrites emanating from CA1 pyramidal cells were stained only after acute ECS (black arrows; B1). B and B1 are magnified views of CA1; C and C1 are enlargements of CA3; D and D1 are enlargements of the dentate gyrus. Scale bars: A and A1, $350 \mu \mathrm{m} ; \mathrm{others,}$ $45 \mu \mathrm{m}$. 


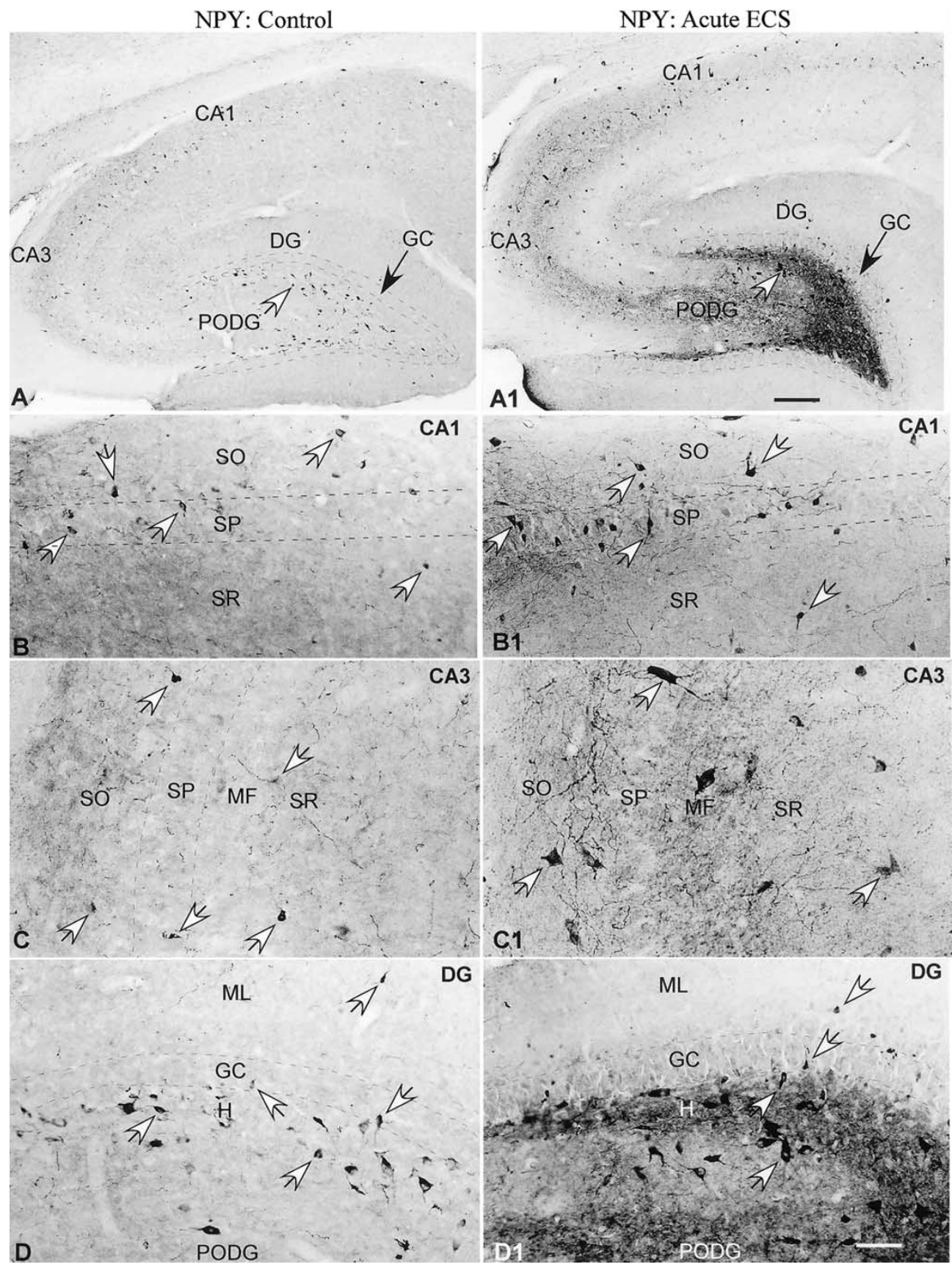

Figure 4. Acute ECS alters expression and localization of NPY. In control animals (A-D), NPY immunoreactivity was primarily localized in scattered interneurons (white arrows) and their intrahippocampal processes, but not in dentate granule cells (dark arrows); intensely stained NPY neurons were prevalent in the hilar area of the dentate gyrus (DG). Following acute ECS (A1-D1), NPY immunoreactivity increased dramatically in the hilar area $(\mathrm{H})$, in polymorph cells of the dentate gyrus (PODG) (D1), in scattered interneurons with processes in the strata oriens (SO), pyramidale (SP) and radiatum (SR) (B1, C1). After a single ECS, NPY immunoreactivity was detected in the mossy fiber bundles close to CA3 (C1) and in dentate granule cells (GC) (D1). B and B1 are magnified from CA1; C and C1 are enlargements of CA3; D and D1 are enlargements of the DG. Scale bars: A and A1, $300 \mu \mathrm{m}$; others, $20 \mu \mathrm{m}$. Abbreviations as in Figure 3.

following a single ECS. The staining patterns in control animals and the responses of cells in the dentate gyrus and hilar area are presented first, followed by data for cells in the CA1-3 regions and for interneurons.
Kalirin, PAM and NPY Protein in Control Hippocampus. Immunohistochemical staining identified kalirin in the granule cells of the dentate gyrus, in the polymorph cells of the dentate gyrus, in the pyramidal cells 
of the CA1-3 regions and in interneurons scattered throughout the hippocampus (not shown). Similar to kalirin, PAM protein in control animals was localized to the granule cells of the dentate gyrus, the pyramidal cells of the CA1-3 regions, the polymorph cells of the dentate gyrus and scattered hippocampal interneurons (Figure 3, panels A-D). In addition, PAM was prevalent in the mossy fibers of control dentate granule cells (Figure 3, panel A, Figure 4, panel C). NPY was primarily localized in scattered interneurons and their intrahippocampal processes. These NPY positive interneurons varied greatly in soma size and morphology and were prevalent in the dentate hilar area (Figure 4, panels A, D). A few scattered NPY positive interneurons were found in the granule cell layer and in the molecular layer of the dentate gyrus (Figure 4, panel D). Under control conditions, NPY mRNA and immunoreactivity were not detectable in the granule cells of the dentate gyrus; NPY immunoreactivity was barely detectable in the mossy fiber terminals (Figure 4, panels A, C, D).

Response of Dentate Gyrus to Acute ECS. Despite a transient increase in kalirin mRNA levels in dentate granule cells, no significant change in kalirin-like immunoreactivity was observed $24 \mathrm{~h}$ after acute ECS (not shown). We previously detected a slight alteration in PAM protein levels and localization following acute ECS (Bhat et al. 1993). Using better reagents, we re-evaluated this response. PAM staining increased in the granule cells of the dentate gyrus, in their mossy fibers, in interneurons and their processes, in the hilar area and in the polymorph cells of the dentate gyrus (Figure 3, panels A1, C1, D1). Quantification of the number of PAM interneurons in the dentate hilar region was not possible because of intense PAM staining in processes in this region. Following a single ECS, there was a dramatic increase in NPY immunoreactivity in the dentate hilar region (Figure 4, panels A1, D1). In addition, NPY immunoreactivity was detected in the granule cells of the dentate gyrus and was slightly increased in their mossy fibers and in the molecular layer of the dentate gyrus (Figure 4, panels A1, C1, D1). To our knowledge, this is the first immunohistochemical study demonstrating that acute ECS resulted in a marked increase in NPY peptide expression in the hippocampus.

CA1-3 Regions. Kalirin immunoreactivity in the pyramidal cells of the CA1-3 regions did not change significantly $24 \mathrm{~h}$ after acute ECS (not shown). In contrast, PAM immunoreactivity was increased (Figure 3, panels B, B1). After acute ECS, PAM immunoreactivity was apparent in the fine dendrites emanating from CA1-3 pyramidal cells and localized in the stratum oriens (Figure 3, panel B1, black arrows). The CA1-3 regions of control animals contained NPY positive interneurons in the stratum pyramidale, but pyramidal cells did not stain for NPY (Figure 4, panels A-C). Acute ECS resulted in a marked increase in NPY immunoreactivity in these interneurons and their processes (Figure 4, panels A1-C1), with no increase in their number (data not shown).

Interneurons. Interneurons scattered throughout the hippocampus of control animals contain kalirin and PAM (Figure 3, panel A). Kalirin immunoreactivity in these interneurons was unchanged following acute ECS. The intensity of the PAM immunostaining in interneurons in the stratum oriens and stratum radiatum of CA1-3 increased following a single ECS (Figure 3, panels B1, C1); the number of PAM containing interneurons was not increased (data not shown). After acute ECS, NPY immunoreactivity in interneurons and their processes in the strata oriens, pyramidale, and radiatum of CA1-3 increased markedly (Figure 4, panels $\mathrm{A} 1-\mathrm{C} 1$ ); the number of NPY positive interneurons in these areas was not increased (data not shown).

\section{Effect of Repeated ECS on mRNA Levels}

The therapeutic effects of ECT require repeated treatments (Abrams 1992). To determine whether peptidergic systems might play a role in this therapeutic response, we compared the changes in kalirin, PAM and NPY mRNA levels after repeated and acute ECS. Two groups of rats received ECS at the same time each day for 12 days. One group was sacrificed $24 \mathrm{~h}$ later (Repeat basal group), while the other group received a final (13th) ECS and was sacrificed $4 \mathrm{~h}$ later ( $4 \mathrm{~h}$ group). Sham controls were removed from their cages and ear clips were attached each day for 12 days, but these animals received no ECS; they were sacrificed on day 13, along with the repeat basal controls.

Dentate Granule Cells and the Hilar Area. Daily repeated ECS did not alter basal levels of kalirin, PAM or NPY mRNA in the dentate granule cells (Figure 5, panels A, B, A1,B1; Figure 2, panels D, E); data for the Sham control and Repeat basal groups were indistinguishable. Importantly, the levels of kalirin, PAM and NPY mRNA in the dentate granule cells increased significantly $4 \mathrm{~h}$ after the 13th ECS (kalirin, $170 \pm 15 \%$ of control, $p<.05 ;$ PAM, $198 \pm 33$ of control, $p<.01$; Figure 2, panel F). At the mRNA level, the hippocampal granule cells were as responsive to ECS after 12 exposures as they were after a single treatment. Importantly, levels of NPY mRNA in interneurons in the dentate hilus were significantly increased in the Repeat basal group and were not further increased following a 13th ECS (Figure 2, panels E, F). As observed for a single ECS, the 13th ECS increased NPY mRNA levels in dentate granule cells and interneurons outside of the hilar area (Figure 2, panel F). 
Kalirin: Repeated ECS
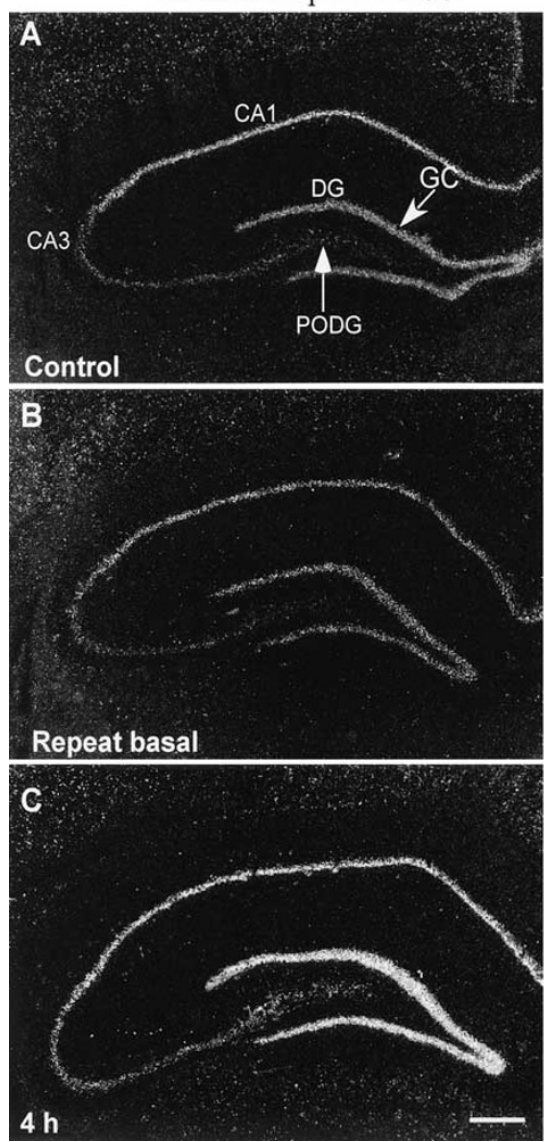

PAM: Repeated ECS
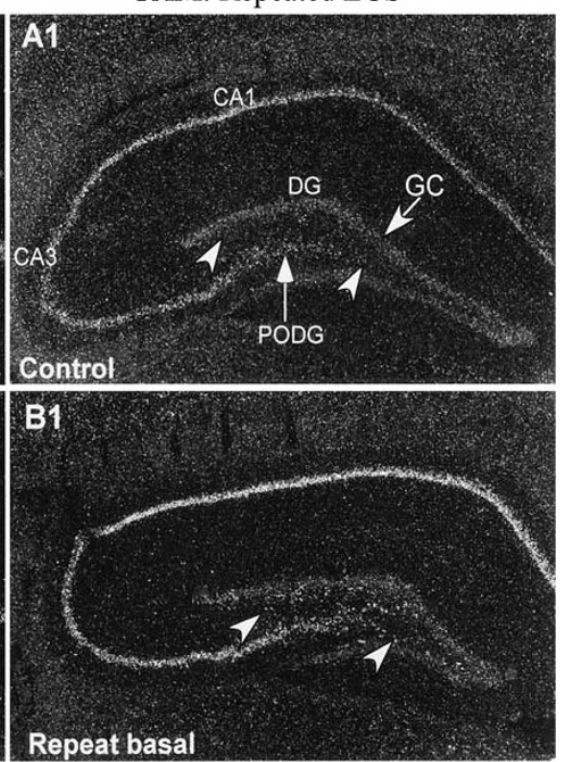

C1

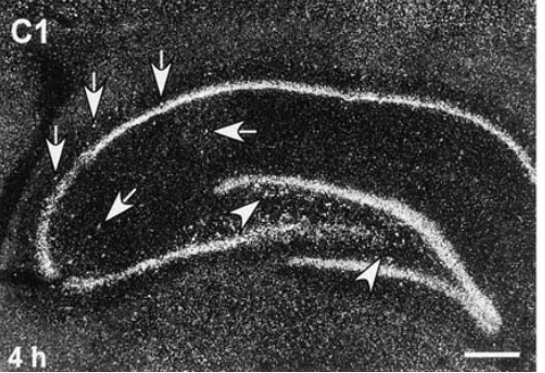

Figure 5. Repeated ECS stimulates kalirin and PAM gene expression. Adult male rats were sacrificed $24 \mathrm{~h}$ after 12 sham ECS treatments (Sham control), $24 \mathrm{~h}$ after 12 ECS treatments (Repeat basal) or $4 \mathrm{~h}$ after a 13th ECS (4 h). Sections were analyzed as described in Figure 1. Data for the Sham control and Repeat basal groups were indistinguishable. Changes in kalirin (A-C) and PAM (A1-C1) mRNA observed $4 \mathrm{~h}$ after the 13th ECS were the same as changes observed $4 \mathrm{~h}$ after a single ECS. Scale bar $=400 \mu \mathrm{m}$. Data were quantified as in Figure $1 ;{ }^{*} p<.05$ vs. sham control, ${ }^{\#}$ $p<.05$ vs. sham control; ${ }^{\# \#} p<.01$ vs. sham control (by 1-way ANOVA followed by Fisher's PLSD test). The entire experiment was replicated two times with similar results.
CA1-3: Daily repeated ECS did not alter basal levels of kalirin or PAM mRNA in CA1-3 pyramidal neurons (Figure 5, panels A, B, A1, B1); data for Sham controls and the Repeat basal groups were identical. As after acute ECS, levels of both kalirin and PAM mRNA in the CA1-3 regions increased significantly $4 \mathrm{~h}$ after a 13th ECS (Figure 5, panels C, C1; kalirin, $125 \pm 7 \%$ of control, $p<$ .05; PAM, $149 \pm 13 \%$ of control, $p<.05)$; the increase in kalirin and PAM mRNA levels was of smaller amplitude in the CA1-3 regions than in the granule cells of the dentate gyrus. NPY mRNA was not detected in CA1-3 pyramidal cells under any of the conditions tested (Figure 2).

Interneurons. Daily repeated ECS did not alter basal levels of kalirin or PAM mRNA in interneurons scattered throughout the hippocampus (Figure 5, panels A, B, A1, B1). As observed with acute ECS, interneurons in the strata oriens and radiatum of CA1-3 and in the dentate hilus had increased levels of PAM mRNA $4 \mathrm{~h}$ after the 13th ECS (Figure 5, panel C1); the responsiveness of these peptidergic markers to ECS was not downregulated. Although kalirin and PAM mRNA levels returned to control values $24 \mathrm{~h}$ following ECS, each ECS resulted in another transient increase in mRNA levels. It was difficult to identify interneurons containing PAM
mRNA in the stratum pyramidale because of high PAM mRNA levels in this region.

In striking contrast, NPY mRNA levels in the interneurons scattered throughout the hilar area actually remained elevated $24 \mathrm{~h}$ after a 12th ECS (Repeat basal). NPY mRNA levels in dentate granule cells and other interneurons returned to control values in the Repeat basal group and continued to increase transiently following a 13th ECS (Figure 2, panels D-F).

\section{Effect of Repeated ECS on Protein Expression}

We reasoned that repeated transient increases in kalirin, PAM, and NPY mRNA levels might result in cumulative effects on protein expression. To evaluate this possibility, we turned to immunohistochemistry. Animals subjected to ECS daily for 12 days were perfused $24 \mathrm{~h}$ after the final ECS (Repeat basal); sham controls were perfused at the same time. Thus, at the time tissue was taken for immunohistochemical analysis, no changes in mRNA levels or localization were detectable except for NPY in the interneurons of the dentate hilus. Data for the dentate gyrus are presented first, followed by data for the CA1-3 region and for interneurons. For all three marker 

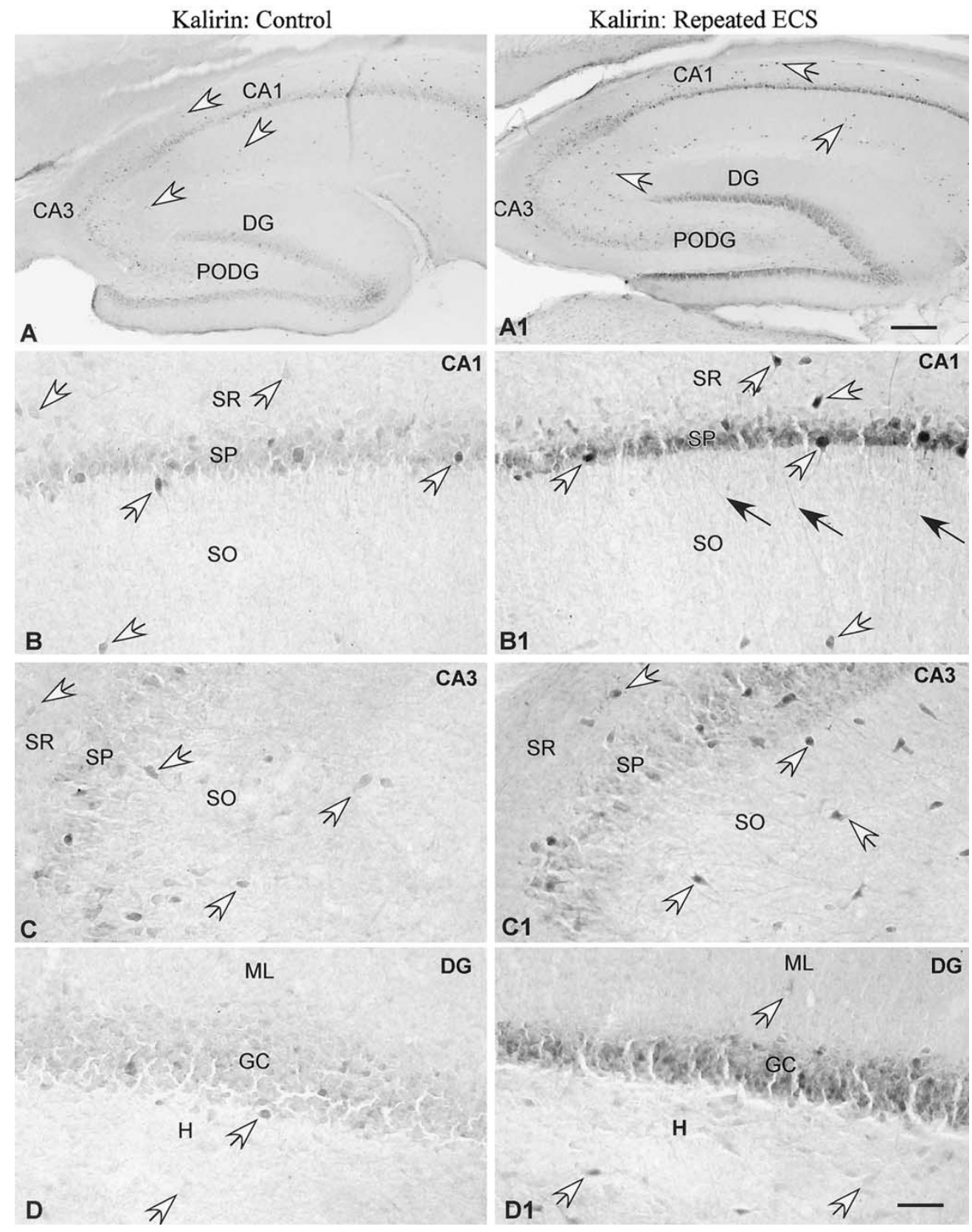

Figure 6. Repeated ECS alters Kalirin expression and localization. Kalirin staining was compared in repeat sham control rats (A-D) and rats receiving repeated ECS (A1-D1) daily for 12 days and sacrificed 24 h later. Kalirin staining in repeat sham controls matched staining in single sham controls (Figure 7, panel A vs. Figure 2, panel A). Repeated ECS increased kalirin immunoreactivity in CA1-3 pyramidal cells, dentate granule cells, PODG and interneurons (white arrows). After repeated ECS, kalirin immunoreactivity was observed in the dendrites of CA1 pyramidal cells and in stratum oriens of CA3 (B1; solid arrows). Abbreviations as in Figure 3. Scale bar: A, A1, $200 \mu \mathrm{m}$; others, $30 \mu \mathrm{m}$.

proteins, marked changes in protein levels and localization were apparent after repeated ECS.

Dentate Gyrus. Kalirin immunoreactivity in dentate granule cells, interneurons and fibers in the dentate hilus increased after repeated ECS (Figure 6, panels A, A1, D, D1). Kalirin staining was detected in the molecular layer of the dentate gyrus, suggesting that it was lo- calized to dendrites. Repeated ECS also increased PAM immunoreactivity in the dentate granule cells and in interneurons of the hilar area (Figure 7, panels A1, D1). Fine dendritic staining of PAM was readily apparent throughout the molecular layer, with especially intense staining in the inner molecular layer (Figure 7, panel D1). After repeated ECS, NPY immunoreactivity was detectable in the soma of dentate granule cells (Figure 

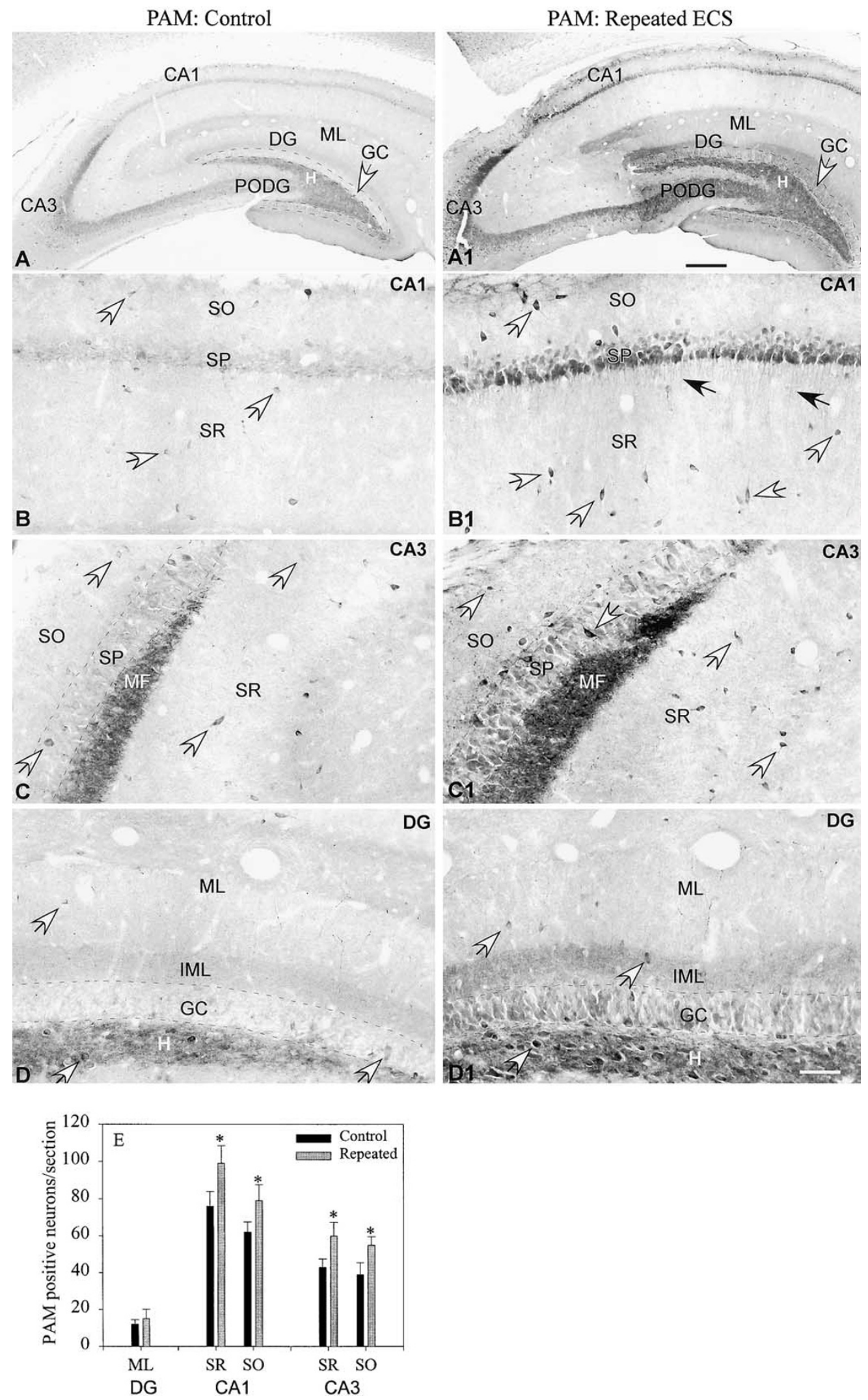

Figure 7. Repeated ECS alters expression and localization of PAM. PAM staining in repeat sham controls looked like PAM staining in single sham controls (Figure 4, panels A-C). One day after the 12th ECS treatment, PAM staining in CA1-3 pyramidal cells, dentate granule cells (GC), PODG and interneurons (white arrows) scattered throughout the hippocampus and hilar area was increased (A1-D1). B and B1 are magnified views of CA1; C and C1 are enlargements of CA3; D and D1 are enlargements of the dentate gyrus. Scale bars: $\mathrm{A}$ and A1, $350 \mu \mathrm{m}$; others, $45 \mu \mathrm{m}$. PAM positive interneurons in the indicated areas were counted in Sham controls and Repeat ECS animals (E). Values are means \pm SEM; ${ }^{*} p<.05$ vs. control. 


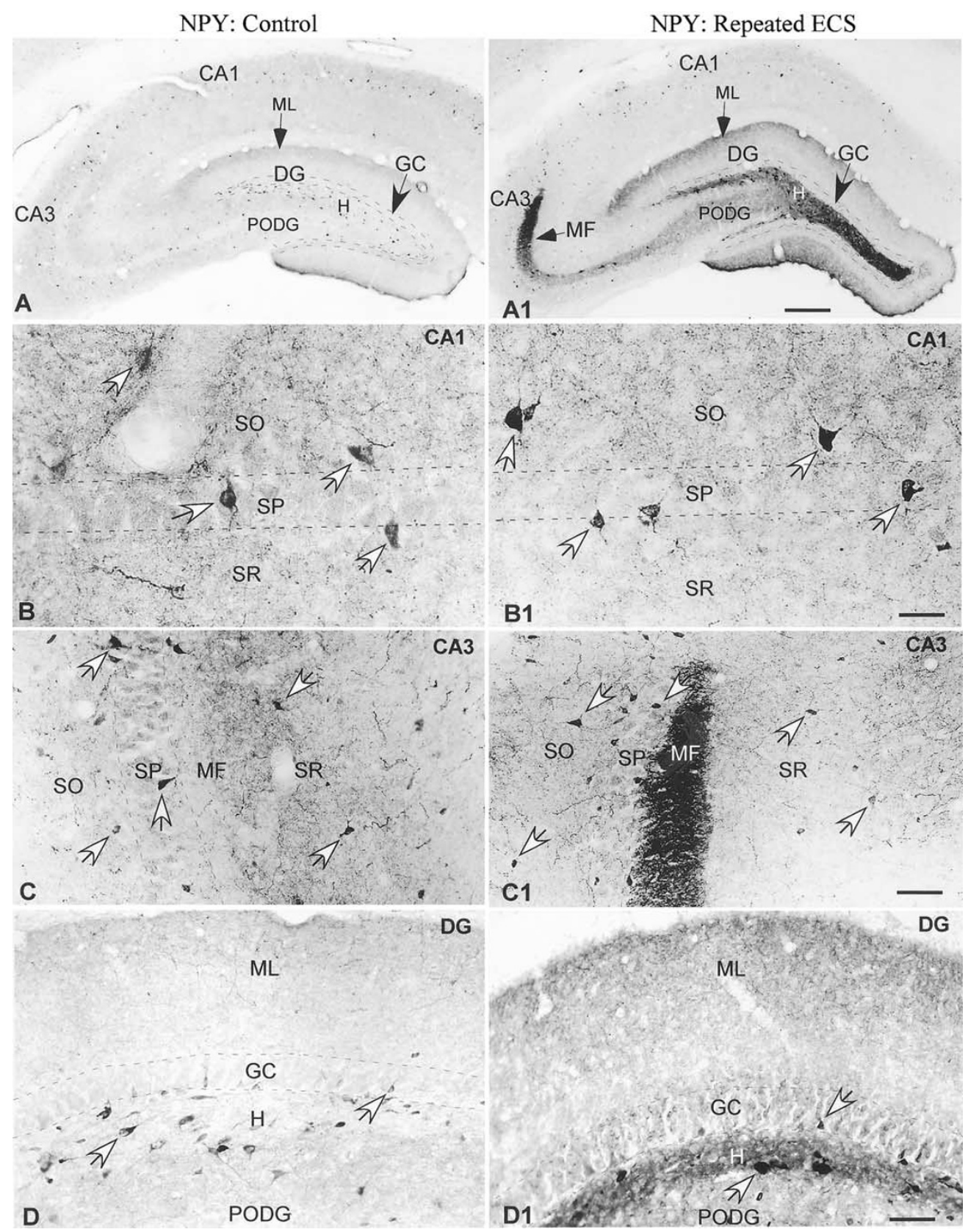

Figure 8. Repeated ECS alters expression and localization of NPY. NPY staining in repeat sham controls was indistinguishable from single sham controls (Figure 5, panels A-D). One day after the 12th ECS treatment, NPY staining in the dentate hilar area, mossy fibers and polymorph cell of the dentate gyrus increased dramatically (A1-D1). NPY staining was detectable in dentate granule cells (D1) after repeated ECS. In contrast, NPY expression in interneurons was unchanged after repeated ECS. B and $\mathrm{B} 1$ are magnified views of CA1; $\mathrm{C}$ and $\mathrm{C} 1$ are enlargements of CA3; D and D1 are enlargements of the dentate gyrus. Scale bars: $\mathrm{A}$ and $\mathrm{A} 1,350 \mu \mathrm{m}$; others, $20 \mu \mathrm{m}$.

8, panel D1). The dramatic accumulation of NPY immunoreactivity in the dentate hilus and the mossy fibers, which make synaptic contacts with the dendrites of CA3 pyramidal cells, is a consequence of the increase in NPY mRNA and presumably in NPY synthesis in the dentate granule cells (Figure 2, Figure 8). Increased NPY immunostaining in fine processes in the outer molecular layer after repeated ECS suggests that NPY transported into the dendrites of the dentate granule cells is involved in intercellular signaling (Figure 8, panel D1). The number of NPY-positive interneurons in the dentate hilus was unchanged following repeated ECS, but staining for NPY was of much greater intensity (Figure 8, panel D1). 
Protein Expression: Repeated vs. Acute ECS
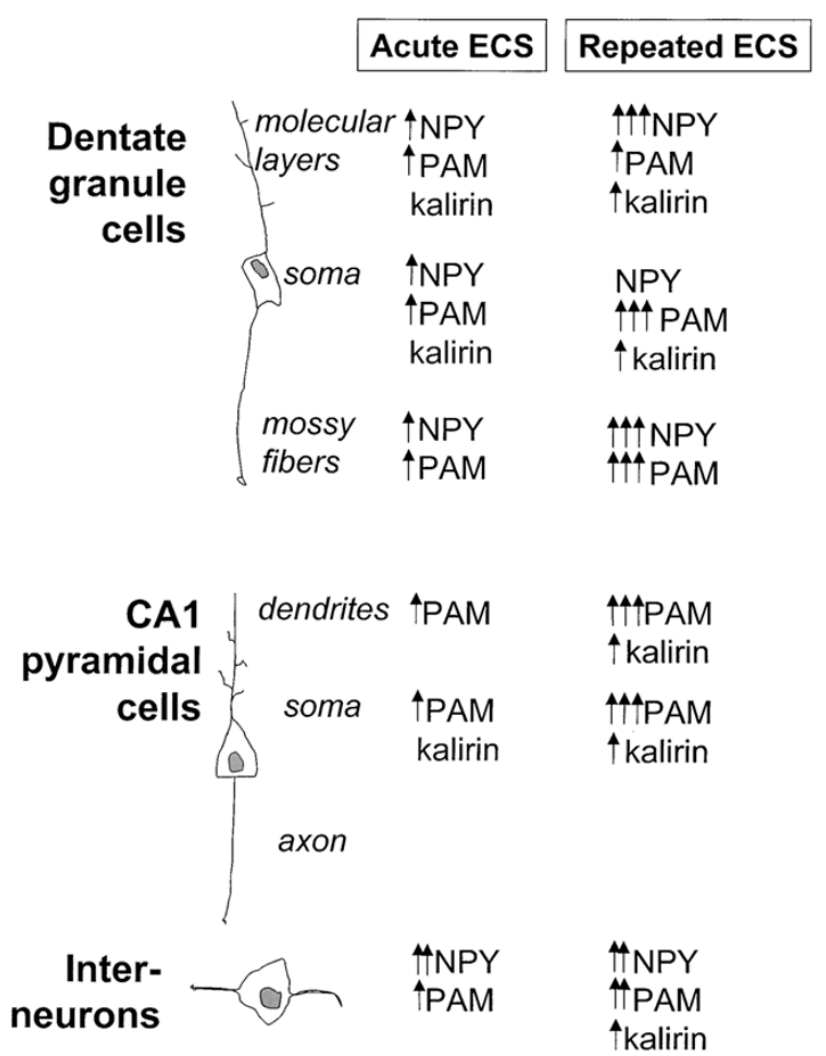

Figure 9. Summary diagram highlighting differences in protein expression in dentate granule cells, pyamidal neurons and interneurons following acute vs. repeated ECS.

CA1-3. Repeated ECS also altered expression of these peptidergic markers in the CA1-3 pyramidal cells. An increase in kalirin immunoreactivity was apparent only after repeated ECS; kalirin immunoreactivity was also detected in fine dendrites extending into the stratum oriens from CA1 pyramidal cells (black arrows, Figure 6, panel B1). Repeated ECS also resulted in increased PAM immunoreactivity in the pyramidal cells of the CA1-3 regions (Figure 7, panels B1, C1). As for kalirin, PAM staining in the dendrites of CA1-3 neurons was readily detected after repeated ECS (black arrows, Figure 7, panels B1, C1). Even after repeated ECS, NPY immunoreactivity was not detected in CA1-3 pyramidal cells (Figure 8, panels B1,C1).

Interneurons. Repeated ECS also resulted in an increase in kalirin immunoreactivity in interneurons scattered throughout the hippocampus (Figure 6, panels A1-C1). Kalirin-positive interneurons were prevalent in the hilar area of the dentate gyrus, in the strata radiatum and oriens of CA1-3, and in the molecular layer of the dentate gyrus. It was difficult to identify interneurons in the stratum pyramidale because of the signifi- cant increase in kalirin staining in pyramidal cells after repeated ECS (Figure 6, panel B1). Repeated ECS increased both the number and staining intensity of PAM positive interneurons in the stratum oriens and radiatum of CA1-3 (white arrows, Figure 7, panels B1, C1). Under basal conditions it was difficult to count the number of PAM-positive interneurons amongst the PAMpositive pyramidal cells. After repeated ECS, intensely stained PAM-positive interneurons were readily identified among the PAM-positive pyramidal cells (white arrow, Figure 7, panel C1). After repeated ECS, interneurons also stained more intensely for NPY (Figure 8, panels A1-C1); the number of NPY positive interneurons in the strata oriens, radiatum and pyramidal of CA1-3 was not increased following repeated ECS.

\section{DISCUSSION}

\section{Acute and Repeated ECS Elicit Similar, Transient Increases in Gene Expression}

After a single ECS, increased levels of NPY, PAM and kalirin mRNA were observed in dentate granule cells (Figure 9). Within $24 \mathrm{~h}$, all three transcripts had returned to control levels. While levels of PAM mRNA peaked $4 \mathrm{~h}$ after ECS, levels of kalirin mRNA did not peak until $8 \mathrm{~h}$. The slower time course observed for kalirin may reflect the larger size of the kalirin gene, which encompasses at least $500 \mathrm{~kb}$ of genomic DNA. Transcription of the entire kalirin gene should take approximately $4 \mathrm{~h}$ since nucleotides are added at a rate of $30-40 \mathrm{bp} / \mathrm{sec}$ (Alberts et al. 1994). Although similar in time course, the increase in PAM and kalirin transcripts in CA1-3 pyramidal neurons following a single ECS was of lesser magnitude. Transcripts encoding these peptidergic markers respond to ECS nearly as quickly as some transcription factors (Cole et al. 1990; Winston et al. 1990).

It is striking that $24 \mathrm{~h}$ after a 12th ECS, levels of PAM and kalirin mRNA were indistinguishable from levels in sham controls. A 13th ECS elicited essentially the same increase in both transcripts as the first ECS; the system was neither sensitized nor desensitized. Expression of NPY was very responsive to ECS. In accord with previous reports, NPY is not expressed in the dentate granule cells of control rats (Morris 1989; Kragh et al. 1994; Zachrisson et al. 1995). After a single ECS, NPY transcripts appear transiently in dentate granule cells, returning to control levels within $24 \mathrm{~h}$. As for PAM and kalirin, $24 \mathrm{~h}$ after a 12th ECS, NPY mRNA levels in dentate granule cells were indistinguishable from sham controls and increased transiently in response to a 13th ECS. In contrast, NPY mRNA levels in hilar interneurons remained elevated $24 \mathrm{~h}$ following a 12th ECS. The sustained increase in NPY expression in this subset of neurons following repeated ECS suggests that they play a unique role in the response. 


\section{Acute ECS Elicits Changes in NPY and PAM Localization}

We evaluated changes in a neuropeptide (NPY), a peptide biosynthetic enzyme (PAM) and a cytosolic protein involved in the trafficking of granule enzymes and cytoskeletal rearrangements (kalirin) (Figure 9). While NPY showed a striking response to acute ECS, the changes in PAM were less dramatic and changes in kalirin were not detectable. NPY staining in the hilar region of the dentate gyrus and in scattered hippocampal interneurons and their processes increased substantially following acute ECS. The number of NPY positive interneurons was unchanged by acute ECS. Consistent with their lack of NPY mRNA, neither dentate granule cells and their mossy fibers nor CA1-3 pyramidal cells stained for NPY under basal conditions. After acute ECS, staining for NPY was apparent in mossy fibers. Expression of NPY in interneurons was found to be more sensitive to neuronal excitation than expression in dentate granule cells (Gruber et al. 1994). Consistent with this, physiological studies indicate that hilar neuron processes penetrate the granule cell layer, reaching the outer molecular layer, and hilar neurons are much more sensitive to afferent stimulation than dentate granule cells (Scharfman 1991).

Acute ECS resulted in an increase in PAM staining in dentate granule cells and in CA1-3 pyramidal cells, along with fine dendrites emanating from the CA1 pyramidal cells $24 \mathrm{~h}$ after acute ECS. PAM is localized to large dense core vesicles, suggesting that these vesicles accumulate in dendrites after ECS, perhaps releasing their bioactive peptides at this location. Despite the changes observed in levels of kalirin mRNA, no significant change in kalirin staining was observed after a single ECS.

\section{Repeated ECS Elicits Marked Changes in NPY, PAM and Kalirin Localization}

Unlike acute ECS, repeated ECS resulted in substantial changes in all three peptidergic markers (Figure 9). Levels of NPY mRNA in the hilar area and hippocampal NPY immunoreactivity were known to increase after repeated ECS (Wahlestedt et al. 1990; Zachrisson et al. 1995; Husum et al. 2000, Jimenez-Vasquez et al. 2000). Consistent with this, dramatic changes in NPY immunostaining were observed following repeated ECS. Previous studies failed to detect the transient increases in NPY mRNA in dentate granule cells after repeated ECS. Repeated ECS resulted in the appearance of NPY immunoreactivity in dentate granule cells, consistent with the accumulation of NPY in mossy fibers. NPY also accumulated in the dentate hilar region. The number of hippocampal interneurons containing NPY was unchanged by repeated ECS, but their NPY content increased.
The accumulation of massive amounts of NPY immunoreactivity in mossy fiber terminals is one of the features distinguishing the responses to acute versus repeated ECS. Mossy fibers originating from the dentate granule cells enter the hilus, where branches form a dense network. In the dentate hilus, a band of fibers traverses the long axis of the hippocampus toward CA3, ending in a dense band in the stratum lucidum, where the mossy fibers synapse with CA3 pyramidal cell dendrites (Frotscher et al. 1994). NPY type $2\left(\mathrm{Y}_{2}\right)$ receptor is present in the presynaptic terminals of mossy fibers in the strata oriens and radiatum of $\mathrm{CA} 3$, on the CA3 pyramidal cells and dentate granule cells. The highest density of $Y_{1}$ receptors is in the molecular layer of the dentate gyrus (Vezzani et al. 2000). Taken together, the dramatic increase of NPY protein in mossy fibers and the appearance of NPY receptors in mossy fibers and dendrites of granule cells after ECS suggest that dentate granule cells may be crucial for inhibiting seizure activity and may contribute to the antidepressive effects of ECT.

NPY-positive interneurons also exhibit different responses to acute and repeated ECS. Many of NPY-containing hippocampal interneurons also contain GABA (Heilig et al. 1990). The NPY/GABA positive interneurons in the hilus send their axons into the outer molecular layer; consistent with this, NPY immunoreactivity in the outer molecular layer of the dentate gyrus increased after repeated ECS. The axons of these interneurons synapse with dentate granule cell dendrites, which have $Y_{1}$ receptors (Vezzani et al. 1999). Axons from NPY positive interneurons in the stratum oriens of CA1 form synapses with the Schaffer collaterals from CA3 pyramidal cells (Vezzani et al. 1999). NPY positive interneurons are thought to regulate excitability by activating presynaptic $\mathrm{Y}_{2}$ receptors at mossy fiber/CA3 pyramidal cell synapses and at Schaffer collateral/CA1 pyramidal cell synapses (Baraban et al. 1997).

Although changes in PAM protein were apparent after a single ECS, repeated ECS led to a much more robust accumulation of PAM protein in dentate granule cells, CA1-3 pyramidal cells, interneurons and polymorph cells. Increased PAM expression was apparent in neurons similar to those exhibiting increased NPY expression after repeated ECS. As for NPY, PAM expression increased in mossy fibers, the molecular layer and in the hilar area of the dentate gyrus. Increased PAM immunoreactivity in CA1-3 pyramidal cells suggests a role for amidated peptides like CCK, which is expressed in pyramidal cell neurons (Sloviter and Nilaver 1987; Stengaard-Pedersen et al. 1983). ECS increases levels of several amidated peptides including TRH, EEP (pGlu-Glu-Pro- $\mathrm{NH}_{2}$; Single letter code for Glu $=\mathrm{E}$, Pro $=\mathrm{P}$ ), neurokinin and CCK (Kubek et al. 1985; Stenfors et al. 1989; Orzi et al. 1990; Mathe 1999; Pekary et al. 1999, 2000). Hippocampal levels of other 
amidated neuropeptides (e.g. substance $\mathrm{P}$, vasoactive intestinal polypeptide and galanin) are unaffected by repeated ECS (Stenfors et al. 1989; Mathe 1999). The cumulative increases in PAM protein in the hippocampus after repeated ECS suggest major roles for amidated peptides in the response to ECT, for example as autocrine growth factors. Both NPY and PACAP stimulate division of the progenitor cells that give rise to olfactory receptor neurons (Hansel et al. 2001a,b). Generation of new neurons in the hippocampus may contribute to the antidepressant effect of ECT (Madsen et al. 2000; Malberg et al. 2000; Scott et al. 2000) and could be controlled in part by amidated peptides.

No change in kalirin localization was observed after acute ECS. Nevertheless, the transient increases in kalirin mRNA that occurred in response to each ECS integrated to yield increased kalirin immunoreactivity in dentate granule cells, scattered interneurons and CA1 pyramidal cells. Like PAM, kalirin staining in CA1 pyramidal cell dendrites and granule cell dendrites was increased. Kalirin could be involved in the remodeling and structural alterations that must underlie the long-term effects of ECT. Chronic ECS induces sprouting of mossy fibers in the hippocampus (Gombos et al. 1999). Kalirin is known to alter the morphology of spine-like structures in cultured hippocampal neurons, to affect cytoskeletal organization and peptide secretion and to affect process outgrowth and branching in sympathetic neurons (Penzes et al. 2000; Mains et al. 1999; May et al., In press). The changes in NPY, PAM and kalirin expression that are unique to repeated ECS provide a target for further investigation into the mechanisms through which ECT ameliorates depression.

\section{ACKNOWLEDGMENTS}

This work was supported by a grant from the National Institutes of Health (DA-00266). We thank Jian-Ping Huang and Darlene D'Amato for general laboratory assistance, Dr. Keith Gary, Dr. Nick De Martinis and Dr. Andy Winokur for helping us to appreciate how ECT is used clinically and members of the Neuropeptide Lab for many vigorous discussions and productive suggestions.

\section{REFERENCES}

Abrams R (1992): Electroconvulsive Therapy. New York, Oxford University Press, p 231

Alam MR, Johnson RC, Darlington DN, Hand TA, Mains RE, Eipper BA (1997): Kalirin, a cytosolic protein with spectrin-like and GDP/GTP exchange factor-like domains that interacts with peptidylglycine alpha-amidating monooxygenase, an integral membrane peptideprocessing enzyme. J Biol Chem 272:12667-12675

Alberts B, Bray D, Lewis J, Raff M, Roberts KE, Watson JD (1994): Molecular biology of the cell. 3rd Ed. Garland Pub, NY, p 368
Argyropoulos SV, Nutt DJ (2000): Substance P antagonists: novel agents in the treatment of depression. Expert Opin Investig Drugs 9:1871-1875

Baraban SC, Hollopeter G, Erickson JC, Schwartzkroin PA, Palmiter RD (1997): Knock-out mice reveal a critical antiepileptic role for neuropeptide Y. J Neurosci 17: 8927-8936

Bhat RV, Tausk FA, Baraban JM, Mains RE, Eipper BA (1993): Rapid increases in peptide processing enzyme expression in hippocampal neurons. J Neurochem 61:1315-1322

Cole AJ, Abu-Shakra S, Saffen DW, Baraban JM, Worley PF (1990): Rapid rise in transcription factor mRNAs in rat brain after electroshock-induced seizures. J Neurochem 55:1920-1927

DePrato Primeaux S, Holmes PV, Martin RJ, Dean RG, Edwards GL (2000): Experimentally induced attenuation of neuropeptide-Y gene expression in transgenic mice increases mortality rate following seizures. Neurosci Lett 287:61-64

Fink M (2001): Convulsive therapy: a review of the first 55 years. J Affect Disord 63:1-15

Frotscher M, Soriano E, Misgeld U (1994): Divergence of hippocampal mossy fibers. Synapse 16:148-160

Gjerris A, Widerlov E, Werdelin L, Ekman R (1992): Cerebrospinal fluid concentrations of neuropeptide $\mathrm{Y}$ in depressed patients and in controls. J Psychiatry Neurosci 17:23-27

Gombos Z, Spiller A, Cottrell GA, Racine RJ, McIntyre Burnham W (1999): Mossy fiber sprouting induced by repeated electroconvulsive shock seizures. Brain Res 844:28-33

Green AR, Nutt DJ (1987): Psychopharmacology of repeated seizures: possible relevance to the mechanisms of action of ECT. In Iversen LL, Snyder SH (eds), Handbook of Psychopharmacology. New York, Plenum Press, pp 375-419

Gruber B, Greber S, Rupp E, Sperk G (1994): Differential NPY mRNA expression in granule cells and interneurons of the rat dentate gyrus after kainic acid injection. Hippocampus 4:474-482

Hall A (1998): Rho GTPases and the active cytoskeleton. Science 279:509-514

Hansel DE, May V, Eipper BA, Ronnett GV (2001a): Pituitary adenylyl cyclase-activating peptides and alpha-amidation in olfactory neurogenesis and neuronal survival in vitro. J Neurosci 21:4625-4636

Hansel DE, Eipper BA, Ronnett GV (2001b): Neuropeptide Y functions as a neuroproliferative factor. Nature 410: 940-944

Heilig M, McLeod S, Brot M, Heinrichs SC, Menzaghi F, Koob GF, Britton KT (1993): Anxiolytic-like action of neuropeptide $\mathrm{Y}$ : mediation by $\mathrm{Y} 1$ receptors in amygdala, and dissociation from food intake effects. Neuropsychopharmacology 8:357-363

Husum H, Mikkelsen JD, Hogg S, Mathe AA, Mork A (2000): Involvement of hippocampal neuropeptide $Y$ in mediating the chronic actions of lithium, electroconvulsive stimulation and citalopram. Neuropharmacology 39:1463-1473

Jimenez Vasquez PA, Salmi P, Ahlenius S, Mathe AA (2000): Neuropeptide $\mathrm{Y}$ in brains of the Flinders Sensitive Line 
rat, a model of depression. Effects of electroconvulsive stimuli and d-amphetamine on peptide concentrations and locomotion. Behav Brain Res 111:115-123

Kanamatsu T, McGinty JF, Mitchell CL, Hong JS (1986): Dynorphin- and enkephalin-like immunoreactivity is altered in limbic-basal ganglia regions of rat brain after repeated electroconvulsive shock. J Neurosci 6:644-649

Kelsey JE, Nemeroff CB (1998): Affective disorders. In Enna SJ, Coyle JT (eds), Pharmacological Management of Neurological and Psychiatric Disorders. New York, McGraw-Hill, pp 95-136

Kragh J, Tonder N, Finsen BR, Zimmer J, Bolwig TG (1994): Repeated electroconvulsive shocks cause transient changes in rat hippocampal somatostatin and neuropeptide $\mathrm{Y}$ immunoreactivity and mRNA in situ hybridization signals. Exp Brain Res 98:305-313

Kubek MJ, Meyerhoff JL, Hill TG, Norton JA, Sattin A (1985): Effects of subconvulsive and repeated electroconvulsive shock on thyrotropin-releasing hormone in rat brain. Life Sci 36:315-320

Ma XM, Lightman SL, Aguilera G (1999): Vasopressin and corticotropin-releasing hormone gene responses to novel stress in rats adapted to repeated restraint. Endocrinology 140:3623-3632

Ma XM, Johnson RC, Mains RE, Eipper BA (2001): Expression of kalirin, a neuronal GDP/GTP exchange factor of the trio family, in the central nervous system of the adult rat. J Comp Neurol 429:388-402

Madsen TM, Treschow A, Bengzon J, Bolwig TG, Lindvall O, Tingstrom A (2000): Increased neurogenesis in a model of electroconvulsive therapy. Biol Psychiatry 47:1043-1049

Mains RE, Alam MR, Johnson RC, Darlington DN, Back N, Hand TA, Eipper BA (1999): Kalirin, a multifunctional PAM COOH-terminal domain interactor protein, affects cytoskeletal organization and ACTH secretion from AtT-20 cells. J Biol Chem 274:2929-2937

Malberg JE, Eisch AJ, Nestler EJ, Duman RS (2000): Chronic antidepressant treatment increases neurogenesis in adult rat hippocampus. J Neurosci 20:9104-9110

Mathe AA (1999): Neuropeptides and electroconvulsive treatment. J ECT 15:60-75

Mathe AA, Jimenez PA, Theodorsson E, Stenfors C (1998): Neuropeptide $Y$, neurokinin A and neurotensin in brain regions of Fawn Hooded "depressed", Wistar, and Sprague Dawley rats. Effects of electroconvulsive stimuli. Prog Neuropsychopharmacol Biol Psychiatry 22: 529-546

May V, Schiller MR, Epper BA, Mains RE (In press): Kalirin Dblhomology GEF1 domain initiates new axon outgrowths through Rho G-mediated mechanisms. J Neurosci

Milgram SL, Chang EY, Mains RE (1996): Processing and routing of a membrane-anchored form of proneuropeptide Y. Mol Endocrinol 10:837-846

Mikkelsen JD, Woldbye D, Kragh J, Larsen PJ, Bolwig TG (1994): Electroconvulsive shocks increase the expression of neuropeptide Y (NPY) mRNA in the piriform cortex and the dentate gyrus. Mol Brain Res 23:317-322

Morris BJ (1989): Neuronal localisation of neuropeptide $Y$ gene expression in rat brain. J Comp Neurol 290:358368
Oyarce AM, Hand TA, Mains RE, Eipper BA (1996): Dopaminergic regulation of secretory granule-associated proteins in rat intermediate pituitary. J Neurochem 67:229-241

Orzi F, Zoli M, Passarelli F, Ferraguti F, Fieschi C, Agnati LF (1990): Repeated electroconvulsive shock increases glial fibrillary acidic protein, ornithine decarboxylase, somatostatin and cholecystokinin immunoreactivities in the hippocampal formation of the rat. Brain Res 533: 223-231

Pekary AE, Sattin A, Lloyd RL (1999): Electroconvulsive seizures increase levels of pGlu-Glu-Pro-NH2 (EEP) in rat brain. Peptides 20:107-119

Pekary AE, Meyerhoff JL, Sattin A (2000): Electroconvulsive seizures modulate levels of thyrotropin releasing hormone and related peptides in rat hypothalamus, cingulate and lateral cerebellum. Brain Res 884:174-183

Penzes P, Johnson RC, Alam MR, Kambampati V, Mains RE, Eipper BA (2000): An isoform of kalirin, a brain-specific GDP/GTP exchange factor, is enriched in the postsynaptic density fraction. J Biol Chem 275:6395-6403

Penzes P, Johnson RC, Sattler R, Zhang X, Huganir RL, Kambampati V, Mains RE, Eipper BA (2001): The neuronal Rho-GEF Kalirin-7 interacts with PDZ domaincontaining proteins and regulates dendritic morphogenesis. Neuron 29:229-242

Prigge ST, Mains RE, Eipper BA, Amzel LM (2000): New insights into copper monooxygenases and peptide amidation: structure, mechanism and function. Cell Mol Life Sci 57:1236-1259

Scharfman HE (1991): Dentate hilar cells with dendrites in the molecular layer have lower thresholds for synaptic activation by perforant path than granule cells. J Neurosci 11:1660-1673

Scott BW, Wojtowicz JM, Burnham WM (2000): Neurogenesis in the dentate gyrus of the rat following electroconvulsive shock seizures. Exp Neurol 165:231-236

Sloviter RS, Nilaver G (1987): Immunocytochemical localization of GABA-, cholecystokinin-, vasoactive intestinal polypeptide-, and somatostatin-like immunoreactivity in the area dentata and hippocampus of the rat J Comp Neurol 256:42-60

Stenfors C, Theodorsson E, Mathe AA (1989): Effect of repeated electroconvulsive treatment on regional concentrations of tachykinins, neurotensin, vasoactive intestinal polypeptide, neuropeptide $\mathrm{Y}$, and galanin in rat brain. J Neurosci Res 24:445-450

Stengaard-Pedersen K, Fredens K, Larsson LI (1983): Comparative localization of enkephalin and cholecystokinin immunoreactivities and heavy metals in the hippocampus. Brain Res 273:81-96

Threadgill R, Bobb K, Ghosh A (1997): Regulation of dendritic growth and remodeling by Rho, Rac, and Cdc42. Neuron 19:625-634

Vezzani A, Sperk G, Colmers WF (1999): Neuropeptide Y: emerging evidence for a functional role in seizure modulation. Trends Neurosci 22:25-30

Wahlestedt C, Blendy JA, Kellar KJ, Heilig M, Widerlov E, Ekman R (1990): Electroconvulsive shocks increase the concentration of neocortical and hippocampal neuropeptide $\mathrm{Y}$ (NPY)-like immunoreactivity in the rat. Brain Res 507:65-68 
Widerlöv E, Wahlestedt C, Håkanson R, Ekman R (1986): Altered brain neuropeptide function in psychiatric illness - with special emphasis on NPY and CRF in major depression. Clin Neuropharamcol 9(Suppl):572-574

Widerlöv E, Lindstrom LH, Wahlestedt C, Ekman R (1988): Neuropeptide $\mathrm{Y}$ and peptide $\mathrm{YY}$ as possible cerebrospinal fluid markers for major depression and schizophrenia, respectively. J Psychiatr Res 22:69-79

Wilson RI, Nicoll RA (2001): Endogenous cannabinoids mediate retrograde signaling at hippocampal synapses. Nature 410:588-592

Winston SM, Hayward MD, Nestler EJ, Duman RS (1990): Chronic electroconvulsive seizures down-regulate expression of the immediate-early genes c-fos and c-jun in rat cerebral cortex. J Neurochem 54:1920-1925
Zachrisson O, Mathe AA, Stenfors C, Lindefors N (1995): Limbic effects of repeated electroconvulsive stimulation on neuropeptide $\mathrm{Y}$ and somatostatin mRNA expression in the rat brain. Mol Brain Res 31:71-85

Zetterstrom TS, Pei Q, Grahame-Smith DG (1998): Repeated electroconvulsive shock extends the duration of enhanced gene expression for BDNF in rat brain compared with a single administration. Brain Res Mol Brain Res 57:106-110

Zobel AW, Nickel T, Kunzel HE, Ackl N, Sonntag A, Ising M, Holsboer F (2000): Effects of the high-affinity corticotropin-releasing hormone receptor 1 antagonist R121919 in major depression: the first 20 patients treated. J Psychiatr Res 34:171-181 